\title{
PEDAGOGY
}

\section{RUSSIANIZATION POLICY OF TSARISM AND BULLYING IN GEORGIAN EDUCATIONAL SPACE ACCORDING TO THE GEORGIAN PRESS OF THE 80S AND 90S OF THE 19TH CENTURY GEORGIANS' FIGHT FOR THE PROTECTION OF GEORGIAN LANGUAGE}

\author{
Imeri Basiladze, Professor \\ Sophio Panchulidze, Academic Doctor of Education \\ Akaki Tsereteli State University, Georgia
}

DOI: https://doi.org/10.31435/rsglobal_ijitss/30062019/6535

\section{ARTICLE INFO}

Received 12 April 2019

Accepted 24 June 2019

Published 30 June 2019

\section{KEYWORDS}

mute method, Georgian press, bullying in Georgian educational space, the native language, national ideas.

\begin{abstract}
In 1801 after invading Georgia, Russia started to fight hard to break Georgian national consciousness, for this it was necessary to demolish the Georgian language. There are many noteworthy notes about the current situation in the magazines and newspapers of 80s and 90s of the 19th century which were published in Kutaisi. Here you will find information how the native language was prohibited, the study of Georgian children was restricted, and the schools were guided by Russians. "Mute Method" was introduced at schools. Russia tried to prove the unnecessity of the Georgian language. For example, if the number of Georgians in one of the educational institutions exceeded the number of other ethnicities, they tried not to find the learners who came from different parts of Georgia as Georgians in order to avoid the need for teaching Georgian language.

At the same time, on the paper of the Georgian press you can find some speeches, protests. Some schools were closed. Georgians demanded the change of educational system. In general, all these served to protect the Georgian language and to strengthen its positions.

Thus, in the 80s and 90s of the 19th century, the Georgian press leaders strictly criticized Russia's Tsarism educational policy because it did not meet the interests of the Georgian people. They thought that the content of the teaching should reflect the true nature of the people. It should be an active propagandist and conductor of national ideas.
\end{abstract}

Citation: Imeri Basiladze, Sophio Panchulidze. (2019) Russianization Policy of Tsarism and Bullying in Georgian Educational Space According to the Georgian Press of the 80s and 90s of the 19th Century Georgians' Fight for the Protection of Georgian Language. International Journal of Innovative Technologies in Social Science. 4(16). doi: 10.31435/rsglobal_ijitss/30062019/6535

Copyright: (C) 2019 Imeri Basiladze, Sophio Panchulidze. This is an open-access article distributed under the terms of the Creative Commons Attribution License (CC BY). The use, distribution or reproduction in other forums is permitted, provided the original author(s) or licensor are credited and that the original publication in this journal is cited, in accordance with accepted academic practice. No use, distribution or reproduction is permitted which does not comply with these terms.

In 1801 Russia after having invaded Georgia, started to fight hard to break Georgian national consciousness, for this, it was necessary to demolish the Georgian language. For this purpose, the Georgian language was methodically persecuted by schools, not the history of Georgia and geography were taught, the oldest national traditions of culture and literacy were neglected. In this way Tsarist Russia wanted the politically dependent nation to break up spiritually.

Active bullying against the Georgian language and culture started in the 70s of the 19th century, when "according to the decree of 21 December 1873 of the Caucasian Empowerment the 
teachers of local languages and other religious faiths had been removed from the staff in the gymnasiums and schools and had been left only on the basis of hourly paid regulation; the 4th point of the order provided teaching local languages with only the students' desire" [5. p. 25].

Schools in Western Georgia experienced the pressure of Tsarism on education policy. There were many noteworthy notes published about the current situation in the 80s and 90s of the 19th century in the magazines and newspapers published in Kutaisi. Here you will find the notes how the native language was banned, learning the children of Georgians was restricted, the schools were guided by the Russians, at the same time there were speeches, protests, schools' closure, demanding the change of the educational system. In general, they served to protect the Georgian language and to strengthen its positions.

In the 80s of the 19th century, Kiril Petre Yanovski was appointed as the curator of the Caucasian learning district in Georgia. He initially began to hypocritically and flatteringly conduct anti-Georgian policy in Georgia. He tried to gain the trust of the leaders of the leading intellectuals and the national liberation movement, and from the beginning, he was able to do it. He "supported" the opening of the special technological high school in Tbilisi, expressing the will of Georgians and Georgian intellectuals as well as Georgian youth, but he needed this fact only to gain trust, but in fact, he was against it.

From the beginning of the $1880 \mathrm{~s}$, in the context of strengthening the reaction, the danger of the destruction of the native language, the culture and the church - the symbols of the individuality of the Georgian people, became more apparent. The disconnecting policy of the Russian authorities was also a serious threat to the national integrity of the Georgian people. In this respect, it is particularly noteworthy that in the 80s and 90s of the 19th century, the newspaper "Shepherd" was responsible for preserving the Georgian language. "We have joined a big empire to gather up the broken parts of Iveria, to unite them and do the national work with united force ... But [the Russians] are working so that this unity does not occur between us. Its division and disintegration are their hellish ideals "[1. p. 6].

Georgian public figures and public teachers were not only fighting in terms of protecting national interests, but they also represented a simple pedagogical view that it is impossible to open the mind of the child without using mother tongue.

Russia was trying to decimate and degrade small nations by restricting the native language and then by completely abolishing it as it wanted the national spirit to be lost in a new generation, limiting the mother tongue and abolishing it took place mainly in the primary schools, so that future generation lost their native language at the beginning of the upbringing. The Russian officials were well aware that if Georgian youth lost their native language from the beginning, they would lose their main national character and treasure (Georgian spirit) and it would be easier for their national degradation or "Russification". That's why the first thing Russia did for national degradation was the attack on the Georgian language. For which their Russian language was introduced to primary schools and taught by the "mute" method. "We briefly explain the so-called "Mute Method": Director of Public Schools of Kutaisi, Levitski, created a new textbook instead of the Russian language textbook "Русское Слово" by Iakob Gogebashvili, which was built on the "mute method": the Russian language should be learned to the child and at the same time they should be able to hear Georgian. In this way, the possibility of studying the Georgian language was completely lost, which was the political side of the textbook, and methodically it did not meet the minimum guidelines. The teaching department, of course, had approved the Levitski book as a guide. Levitski tried to spread his own textbook instead of "Русское Слово" by Gogebashvili. Gogebashvili's protest stayed just a protest. The "mute method" served the policy of expulsion of Georgian language from Samegrelo and Svaneti schools too. The government took measures to make up the alphabet for the Megrelian language, the same Russian alphabet, to translate migratory prayers and to perform the liturgy in the Megrelian language. Such a policy was directed by Russia against Svaneti and Abkhazia. Of course, the Georgian intellectuals did not understand this and first of them was the editor of the newspaper "Shepherd" - Davit Gambashidze. He expressed regret over this anti-Georgian phenomenon: "We have never heard from anyone that the Georgian language for the Megrelians is a foreign language as some people think ... It is a mistake, even Megrelian is considered to be in a linguistic group that is different from Georgian, and that is not just ignorance, but it is completely deliberately for violation of the Unity of the Georgians" [2. p. 10].

All the above said was added with the fact, that "teaching in every kind of school, including in elementary schools is dogmatic. Learning goes uninterruptedly, like the secondary schools of the middle centuries, upbringing, the moral side had fallen, distorted". The study materials of the subjects basically have to be cited. The pupils are asked to learn almost everything: poems, stories, grammar 
and arithmetic rules, all major prayers by heart. All these make elementary school - the main link of public education almost useless "[3. p. 42].

In 1881, Yanovsky, the caretaker of the learning district, asked the viceroy of the Caucasus, Mikheil Romanov, to approve a new curriculum - «Об учебном плане школы в среде туземного населения по постановке в ней русского языка» [4. p. 35]. With this plan learning the Russian language should start from the second half of the first year of primary schooling and teaching subjects gradually should be started in the Russian language from the same year. The Society for the Spreading of Literacy, the advanced teachers and Georgian intellectuals did not consider this fact as good, they thought it would be better if the Russian language would start from the third year of teaching, since the child's native language was already well known, they could easily learn a new language, but the Russian government did not compromise.

In accordance with the 1881 circular, the management was forced to start enhanced teaching the Russian language from the very first class, of course, at the expense of the lessons defined for the native language, and according to the instruction of the leadership of the Kutaisi provincial (Levitski), from 1890, gymnasium teaching had to be conducted entirely in Russian. The strengthening of the Russification is also well expressed in the 1892-1893 Curriculum of the Tbilisi Women's Diocesan School, according to which the Georgian language and spelling in the preparatory class were taught only for two hours; While the Russian language was taught for six hours, the Russian spelling - for four. It was added with two weekly hours to study the Ecclesiastical-Slavic chant. The number of the Georgian language and spelling lessons decreased to one hour at the top level of teaching; The Russian language should be increased to five (instead of four) weekly hours and teaching spelling to four (instead of three) weekly hours. The situation in the diocese school of women caused a fair upset of the Georgian society: "Teaching of mother tongue is only done in this institution when the parents of the apprentices spend a special expenditure on this subject annually... What kind of mothers should be the women who have almost forgotten their mother tongue and because of that, they are also unable to learn another foreign language! What kindness will the family have where such unprepared women get right to motherhood?" [6. p. 9].

Russia tried to prove the unnecessity of the Georgian language. One of the examples was the facet: If the number of Georgians in any educational institutions exceeded the number of other ethnicities, they tried to not name Georgian disciples who came from different parts of Georgia as Georgians and in this way they tried to avoid the need for teaching the Georgian language.

The Tsar authority was doing everything for excluding the Georgian language from the learning subjects, inventing new methods to prove its unnecessity. "It is the injustice and against the pedagogical demands to teach literary Georgian language Megrelians, Svans, Abkhazians, and Ossetians. If the nation (i.e., those listed above) do not have the writings and the language of the liturgy, they should be taught Russian and Slavian!" [1. p. 6]. "One of the subjects which are a hindrance for our education, to which no attempt and labor succeed. That's because this subject comes outside the door and is independent of us. We are speaking about Russian. This obstacle mainly is that the study of this subject is a great deal of hindrance of our teenage youngsters' intelligence"[1. p. 6].

In order to create a Megrelian alphabet an alumnus of the University Oriental faculty Al. Gren came from St. Petersburg. He knew the Georgian language quite well. Gren soon made the Megrelian alphabet up. He also had an opponent in Samegrelo, Tada Ashordia, a teacher of Zugdidi School, who, in his turn, made up "Mother Nina" (Megrelian alphabet).

Some prayers were translated into Megrelian, but the translation was inappropriate and unacceptable for the people. It was so unpleasant that the congregation of Samegrelo denied the liturgical prayer in the Megrelian language.

In 1890, Iakob Svimonidze wrote in one of publications of the newspaper "Shepherd": "The great importance of mother-tongue and nationality for the life and success of the people has become well known in Europe recently, and all the small nations, joined with the large state, try to prove that it is worthy to protect their language, literature, people. The best event in order to achieve the desire will be able to determine and disclose the dignity, merits, and peculiarities of their past life "[8. p. 4].

The Russian government begins to fight against public education directly with the help of schools and teachers, and the schools used human degrading methods as tracking, mocking, abusing, beating and so on. All these served as the desire of the Tsar of Russia to establish a colonial policy and to introduce obedience among the people. The schools were not opened to educate the younger generation but they wanted them to grow up as the royal officials. 
The newspaper "Shepherd" did not change its attitude towards Tsarist educational policies and faithfully defended the position of the Georgian nation and considered that for the development of the nation's awareness it was necessary to educate in the native language. The newspaper Shepherd wrote in one of the 1890's editions: "If we do not teach people mother tongue, it will be forbidding people to open their minds, to develop their spiritual talent; it will leave people in a childish position, and if we make people learn another language instead of their own language, even if this one is a close relation to their mother tongue, it will be worse: we will distort the natural opening of their minds. We will spell the whole spiritual nature ... the language reflects the whole nation and their homeland" [9. p. 8].

One of the key levers of Tsarism education policy was the fact that most of the teachers in the schools of Georgia were of Russian nationalities who did not know the Georgian language and looked at the local population as natives. The newspaper "Labor" correspondent describes the attitude of the teacher and the pupil in the schools of eighty years: "The teacher looks at the student as a slave who he does not know well and does not recognize the human nature of the student and is always threatening him. Pupils have their own ideas too. They recognize the teacher as a despot who does not consider the position of a student, so the student always tries to resist the teacher and seeks the possibility to make him angry, catch up with him in some way, and often this case ends with beating to death and the school trial. "[3. No. 42].

Leading Georgian teachers demand a radical transformation of teaching. They considered the methods of instruction - the catechism of materials and learning by heart, introduced by the Tsar authorities unacceptable.

When the teachers mechanically pushed the students to learn the whole article and other subjects by heart, the minds of the young pupils were not able to open, but they would shatter. It is also worthless the rule of teaching, in which case, the pupils are like soldiers, and they only hear what the teacher tells them. While such teaching, they are just learning a few words of the teacher, but unreasonably and incomprehensibly" [10. p.4].

The Georgian pedagogical opinion appropriately evaluated the study of the regularities of age development of children and adolescents and the gaps in the learning process seemed to be a violation of this requirement.

The abovementioned issues have not lost their sensitivity even today. This fight continues, not so openly as it was at the end of the 19th and at the beginning of the 20th centuries, but still. The Russian invasion policy is still unchanged and today, if it is not able to fully implement its policy in the territory of Georgia, it tries to impose it in the occupied territories of Abkhazia and Samachablo on local ethnic Georgian population. The policy is sometimes successfully implemented.

Thus, in the 80s and 90s of the 19th century, the Georgian press leaders strictly criticized Russia's Tsarism educational policy because it did not meet the interests of the Georgian people. They thought that the content of the teaching should reflect the true nature of the people. It should be an active propagandist and conductor of national ideas.

The topic of violent influence on Georgia has not lost its priority even today. In spite of the modern international outlook, the obvious or hidden struggle for maintaining the influence of the Georgian land still continues, which makes the territorial integrity of the country still impossible.

\section{REFERENCES}

1. Ghambashidze D., "Bitter Thoughts", Journal "Shepherd", 1889, No.7.

2. Journal "Shepherd". 1885 No. 7.

3. $\quad$ Newspaper "Labor", 1882, No. 42.

4. Khundadze T., The Society for the Spreading of Literacy among Georgian (1879-1927), State publishing house "Soviet Georgia" Tbilisi, 1960.

5. Khundadze T., Tsarism Educational Policy in Georgia, Tbilisi, 1940.

6. Journal "Shepherd", 1893, No. 7.

7. Journal "Shepherd", 1889, No. 2.

8. Svimonidze I., Main Errors, Journal "Shepherd", 1890, No. 20.

9. Svimonidze I., Major Errors, Journal "Shepherd", 1890, No. 12.

10. Journal "Shepherd", 1898, No. 14. 